\title{
DIABETES AND MEDICINAL PLANTS - A GLANCE AT THE PAST AND LOOK TO THE FUTURE
}

\author{
A. Nirmala ${ }^{1}$, Mazher Sultana ${ }^{2}$ \\ ${ }^{1}$ Department of Biotechnology, AarupadaiVeedu Institute of Technology, Paiyanoor, \\ Chennai, Tamil Nadu, India. \\ ${ }^{2}$ Department of Zoology, Presidency College, Chennai, Tamil Nadu, India.
}

\begin{abstract}
Diabetes mellitus is a group of metabolic disorder, where in a person has high blood sugar, either because the pancreas does not produce enough insulin, or cells do not respond to the insulin that is produced. Due to the elevated blood sugar level it results in major illness, complications like nephropathy, retinopathy, cardiomyopathy and death may occur all over the world. In fact and with other studies the diabetic people cannot be cured and has no report that some recovered fully from diabetes. For the treatment of diabetes, synthetic drugs which are currently available are found to be connected with many adverse effects. Currently existing anti-diabetic drugs like sulphonylureas, biguanides, including insulin and other hypoglycaemic agents, control the elevated blood sugar level as long as they are administered regularly and they also produce a number of side effects. To avoid this situation use of plants in medicine is an age-long practice in various parts of the globe for both precautionary and therapeutic purposes. The novel drug can be developed by pharmacological screening and using chemical constituents which is present in the medicinal plants and herbs. For the treatment of diabetes many medicinal plants have been used all over the world, but only a few have been analysed and quantified as per the modern system of medicine. The use of these medicinal plants might delay the development of diabetic related complications and correct the metabolic abnormalities also. In recent scenario there is a need for the advance research to develop and characterize some natural drugs from plants and other natural sources with the aid of better screening methods.
\end{abstract}

KEY WORDS: Diabetes mellitus, Hyperglycemia, medicinal plants, Natural source, Modern medicine.

\section{Corresponding author: A.Nirmala*}

\section{INTRODUCTION:}

Diabetes mellitus is a common and most prevalent disease affecting both male and female of developed and developing countries. Diabetes mellitus is characterized by hyperglycaemic condition along with impaired metabolic functions. There are two major types of Diabetes mellitus, the Type-I is characterized by insufficient production of insulin and Type -II diabetes that target cells, which do not respond to insulin. According to the International Federation of Diabetes, 415 million adults around the world are suffering from diabetes, and it is estimated that the numbers will reach around 642 million by 2040 [1]. The first World Health Organization (WHO) global report on diabetes demonstrates that the number of adults living with diabetes has almost quadrupled since 1980 to 422 million adults [2]. Global age standardized the adult diabetes prevalence as $9.8 \%$ among men and $9.2 \%$ among women in 2008, up from $8.3 \%$ and $7.5 \%$ in 1980 [3]. 
In developing countries traditional medicine is used for the treatment of diabetes where the cost of conventional medicines is a burden to the population. Currently, different treatment methods are available for the treatment of diabetes, such as diet therapy, insulin therapy and pharmacotherapy. There are several types of glucose-lowering drugs that exert anti-diabetic effects through different mechanisms but the exploration of new drugs continues and is in progress due to the limitations existing in synthetic drugs [4].

Therefore, an alternative treatment method is required; which is a need of hour to shift towards the different indigenous plant and herbal formulations. Number of medicinal plants has found to be useful in management of diabetes mellitus. Natural plants are the major source of drug either directly or indirectly because of the easy availability and affordability [5].The specific bio active compounds are required to isolate, purify and characterize the specific compounds with the efficacy to control the blood sugar level and regeneration of damaged beta cells of the pancreas for the secretion of insulin. The objective of the review is to elucidate the antidiabetic properties of the medicinal plants used by the traditional healers to manage diabetes mellitus.

\section{Cassia fistula}

Cassia fistula commonly known as golden rain tree, flowering plant, belongs to the family Fabaceae. It is traditionally used by local doctors and in most of the herbal preparation for diabetes [6], antitumor, intestinal disorders [7], anti-inflammatory [8], laxative [9], antipyretic [10]. In alloxan induced diabetes rats, urea and creatinine level were significantly reduced by $C$. fistula ethanol extract [11].

The alkaloids that exist in the ethanolic extracts and water soluble fractions exhibit antidiabetic activity [12]. The leaves of $C$. fistula, ethylacetate extract, possess significant hypoglycemic activity in alloxan-induced diabetic rats [13]. C. fistula possesses antidiabetic potential and the blood sugar; cholesterol levels were similar to the control group [14]. Dose related inhibition of amylase activity was observed in ethanolic root extract treated diabetic rats [15]. Phenolic constituents present in the alcoholic fruit extract of C. fistula were reported for antidiabetic activity [16]. Increased level of GSH was observed in extract treated group [17].

\section{Annona squamosa}

It belongs to the family of Annonaceae, commonly known as custard apple in English. This plant is used for the treatment of jaundice [19], Cancer [20] and also as an anthelminthic [21] and insecticide agent [18]. This plant contains the important compounds like phenolic, glycosides, tannins and flavonoids [22]. Due to the presence of these compounds, the plant has antidiabetic property and also reduces the total serum cholesterol level [23]. The streptozotocin and alloxan-induced rats when treated with aqueous extract of A. Squamosa, the insulin secretion was observed to be enhanced from destructed pancreatic $\beta$ cells [24].

\section{Catharanthus roseus}

Catharanthus roseus belongs to family Apocynaceae, commonly called as nithyakalyani in Tamil, widely distributed throughout the world. This plant is used for the treatment of various disease and disorder such as antibacterial, antimicrobial [25], ulcer [26], antiviral [27], antifertility [28], antioxidant, anticancer [29], antipyretic [30] and antifungal activities [31]. The STZ induced rats treated with $C$. roseus extracts observed an increased level of glucokinase, succinate dehydrogenase, malate dehydrogenase [32] and a significant decrease in serum LDL level. This reduction may be due to the presence of flavonoids and also the increased level of protein was decreased by the treatment of $C$. roseusin alloxaninduced diabetic rats. 


\section{Centella asiatica}

Centella asiatica belongs to family Apiaceae, commonly called as Vallarai in Tamil. All the parts of these plant used to treat various disease such as ulcer [33], psoriasis [34] used as antioxidant [35], wound healing [36]. This plant extract using ethanol and methanol have proved to possess anti-diabetic activity, decrease the blood glucose, cholesterol and triglycerides in diabetes induced animals [37, 38, 39]. The mechanism behind the antihyperglycemic activity of C.asiaticais to reduce carbohydrate breakdown, and glucose fiber binding, which in turn reduces the glucose absorption through the gastrointestinal tract [40].

\section{Cichorium intybus}

Cichorium intybus is commonly called as Kasinikeerai in Tamil and it is placed in the family, Asteraceae. The Chichoric acid compound present in this plant stimulates the immune system and prevents inflammatory and bacterial diseases [41] and act as anticancer [42], antioxidant [43]. In STZ induced diabetic rats with the administration of Methanolic extract of $C$. intybus reduce the level of blood glucose, cholesterol, ketone in urine and increase the HDL cholesterol in diabetic rats $[44,45]$.

\section{Eugenia jambolana}

This plant belongs to the family of Myrtaceae, commonly known as Jamun and Naaval Pazham in Tamil. It is ever green tree indigenous to India and it is cultivated for its fruits. The plant is used for the treatment of various disease and disorder like, Piles [46] and Constipation [47]. The seed of this plant promote the release of insulin [48], decrease in plasma glucose level in patients with type 2 diabetes mellitus [49], restoration of lipid profile was noticed [50] and increases the level of plasma insulin and C-Peptide in diabetic rats [51], reversal of blood urea, blood creatinine and urine micro albumin [52] and regeneration of beta cells in STZ induced rats [53]. Mycominose is a compound that isolated from E. jambolana which significantly reduces the blood glucose level as that of glibenclamide standard [54]. The E. jambolana flower extract possess anti-diabetic activity [55] and also it reverse the blood urea, creatinine, urine micro albumin level in winster rats and also induces the regeneration of beta cells in STZ induced animal [56].

\section{Gymnema sylvestre}

Gymnema sylvestre is a climber belonging to the family, Asclepiadaceae. This plant is used for various disease and disorder such as snake bite and cardiovascular disease [57]. The extract of Gymnema sylvestre (aqueous, methanol extract and other extract) have antidiabetic activity in diabetes induced animals and potentially increase the Secretary granules of $\beta$ cells of pancreatic islets and increase the enzyme activity which is responsible for the uptake and utilization of glucose[58].

\section{Achyranthes aspera}

Achyranthes aspera is a species of plant in the Amaranthaceae family. It is distributed throughout the tropical world. In STZ induced rats the ethanolic extract of Achyranthes aspera significantly reduced their blood glucose level. The decreased effect, probably due to the inhibition of glucose absorption from the intestine [59].

\section{Acacia arabica}

Acacia is the most considerable genus of family: Leguminosae, first of all described by Linnaeus in year 1773. In India Acacia species are commonly called as 'Babool' and ethno medicinally have long been used for the treatment of various problems like skin, 
sexual, stomach and tooth problems. Acacia arabica has been proved as an effective medicine in treatment of malaria; sore throat (aerial part) [60,61, 62, 63, 64, 65]. The antidiabetic activity of Acacia arabica plant was done by oral administration of this bark extract $(200 \mathrm{mg} / \mathrm{kg}$ and $100 \mathrm{mg} / \mathrm{kg})$ in STZ induced diabetic rats, it increased the high serum insulin and in addition insulin resistance decreased. This effect may be due to that plant contains flavonoids, polyphenols and tannins substances with antioxidant properties [66].

\section{Annona squamosa}

To evaluate the anti-diabetic effect if this plant, the aqueous extract of Annona squamosa was administered to STZ induced rats for thirty days. After administration it causes a significant reduction in blood glucose, lipid, lipid peroxidation and increased activity of anti-oxidants enzyme like catalase, SOD. In addition, this extract is effective in preventing diabetic complications caused by lipid peroxidation and antioxidant systems in experimental diabetic rats [67].

\section{Albizia odoratissima}

The methonolic bark extract of ( 250 to $500 \mathrm{mg} / \mathrm{kg}$ body weight) Albizia odoratissima was given to alloxan induced diabetic rats. After administration it was significantly reduced the levels of serum cholesterol, triglycerides, SGOT, SGPT, alkaline phosphatase and decrement of total proteins in alloxan induced albino mice [68].

\section{Catharanthus roseus}

To find the hypoglycemic effect of Catharanthus roseus, the methanolic leaf extract was prepared and administered to alloxan induced diabetic rats, it was found to decrease significantly the blood glucose level when compared to healthy control group. The blood glucose lowering effect of $C$. roseus methanolic extract was more noticeable effect than the Glinbencalmide and metformin [69]

\section{Axonopus compressus}

The methanolic leaf extract of Axonopus compressus was taken in different concentration $(250,500$ and $1000 \mathrm{mg} / \mathrm{kg}$ body weight) and administered to alloxan induced diabetic rats. It shows significantly reduced blood glucose level and found to possess very good hypoglycaemic effect [70]

\section{Caesalpinia digyna}

Caesalpinia is a genus of flowering plants in the legume family, Fabaceae. Antidiabetic effect of Bergenin from the roots of Caesalpinia digyna (C. digyna). The root extract of Caesalpinia digyna has significant effect on lowering the levels of plasma total cholesterol (TC), triglycerides (TG) and LDL-C were significantly decreased, whereas levels of HDL-C were significantly increased in diabetic rats when compared to control group and also levels of antioxidant enzymes such as SOD and CAT were decreased and increased levels of TBARS was observed in diabetic rat compared to control rat. The administration of bergenin $(10 \mathrm{mg} / \mathrm{kg}$; p.o.) significantly increased the SOD and CAT respectively and reduced TBARS level. From the above study it was concluded that Bergenin having very good antidiabetic properties [71].

\section{Ocimum sanctum}

It is commonly known as Holy basil, Tulasi. It is an aromatic perennial plant belongs to the family Lamiaceae. The leaves of this plant have anti diabetic property, consuming doses of Ocimum sanctum (OS) leaf is at $2 \mathrm{gm} / \mathrm{kg}$ for 30 days. In animal study Ocimum 
sanctum treated diabetic albino rats showed a sharp reduction in glucose level and increased levels of antioxidant enzymes. For this reason, the hypoglycemic activity of the plant is assumed to be correlated to the adjustment response of the cellular antioxidant system [72, 73].

\section{Phyllanthus amarus}

Phyllanthus amarus is a medicinal plant included in the Phyllanthaceae family. $P$. amarus is an important plant of Indian Ayurvedic system of medicine which is used for the problems of stomach, genitourinary system, liver, kidney and spleen. It has bitter, astringent, stomachic, diuretic, febrifuge and antiseptic quality. The alloxan induced diabetic treated with oral administration of ethanolic extract from the leaves $(400 \mathrm{mg} / \mathrm{kg} / \mathrm{BW})$ for 45 days caused a significant reduction in blood glucose levels and significant improvement in the body weight of diabetic mice. In addition a reduction in glucose-6-phosphatase and fructose 1, 6 di phosphatase activities of the liver was also observed. The glucokinase activity, in comparison with control group, found to increase after the treatment in the liver of the diabetic rats [74].

\section{Trigonellafoenum graecum}

Trigonellafoenum graecum belongs to the family of Leguminaceae is commonly known as Fenugreek and in Tamil called as Vendhayam. It is very good source of dietary fibres. Traditionally this plant is used as lactation stimulators [75]. It control high cholesterol, GI tract ailments [76] and it has good anticancer property [77]. The fenugreek leaves and seed extract possess the good antidiabetic and hypocholesterolemic properties [78]. Due to the presence of saponins in fenugreek, it is considered to inhibit the occurrence of histopathological changes in the pancreas of alloxan-induced diabetics [79]. Fenugreek administration reduces the level of glucose absorption and may also delay the gastric emptying there by avoiding the rise in blood sugar level [80] due to the presence of compounds like Quercetin, Diosgenin, Trigonelline, Galuctomium and 4-hydroxy isoleucine in it $[81,82]$.

\section{Momordica charantia}

Momordica charantia is commonly called as Bitter gourd, in Tamil it is called as Pagakkai, belongs to the family of Cucurbitaceae. M. charantia possesses good medicinal properties such as antimalarial [83], antifertility [84] and antihelmintic etc [85]. In diabetic rats after administration with extract of M.charantiaa a significant decrease in blood glucose and an increase in the serum insulin level was noticed [86]. Their metabolic profile of the diabetic rats was close to the normal range [87].

\section{Biophytum sensitivum}

Recently researchers reported that, the administration of $B$. sensitivum reduced the activities of gluconeogenic enzymes present in glucose homeostasis and increased the level of plasma insulin which enhances the glycogenesis in streptozotocin and nicotinamide-induced diabetic rats. This treatment helps to prevent an increasing of lipid peroxidation in plasma, pancreas and kidney resulted in the decrease of plasmas insulin level and an increase in aldose reductase activity in kidney [88]

\section{CONCLUSION:}

Diabetes is a metabolic disorder that manifest due to the defects in either insulin secretion, insulin action, or both in developed and developing countries like India. It can leads to serious health problems, in long term effects, it could cause micro and macro 
vascular problem. In addition, uncontrolled diabetes can cause much chronic complication including renal failure, blindness and heart disease etc. For the treatment of diabetes, the available anti-diabetic drugs in the pharmaceutical market might cause a number of side effects. Herbal medicines and plant components with less toxicity and no side effects are distinguished as therapeutic options for the treatment of this disease around the world. The medicinal plants extracts has the ability, due to the presence of natural antioxidants and their anti-diabetic compounds, such as flavonoids, tannins, phenolic, and alkaloids to restore the activity of pancreatic $\beta$-cells to secrete the insulin or decrease the intestinal absorption of glucose. Plants have been reported to possess secondary metabolites with antidiabetic potential. This review cited the activity of various medicinal plants in managing diabetes mellitus in experimental animals.

\section{DECLARATION OF INTEREST}

The authors declare that this article's content has no conflict of interest.

\section{ACKNOWLEDGEMENT}

The authors are thankful to AarupadaiVeedu Institute of technology, Vinayaka Missions Research Foundation and My Research Supervisor, Dr. Mazher Sultana for her, guidance, support and help.

\section{REFERENCE:}

1. International Diabetes Federation (IDF).(2015). IDF Diabetes Atlas. 7th ed. Available from: http://www.idf.org/idf-diabetesatlas-seventh-edition.[Last accessed on 2016 May $11]$.

2. World Health Organization. (2016).Global Report on Diabetes. Available from: http://www.who.int/diabetes/global-report/en/. [Last accessed on 2016 May 11].

3. Danaei, G., Finucane, M.M., Lu, Y., Singh, G.M., Cowan, M.J., \&Paciorek, C.J.(2011).National, regional, and global trends in fastingplasma glucose and diabetes prevalence since 1980: Systematic analysis of health examination surveys and epidemiologicalstudies with 370 country-years and 2.7 million participants. Lancet, 378,31-40.

4. Arumugam, G., Manjula, P., \&Paari, N.(2013). A Review: Anti diabetic medicinal plants used for diabetes mellitus. JAcute diseases, 2(3),196-200.

5. Yakubu, M.T., Sunmonu, T.O., Lewu, F.B., Ashafa, A.O.T., Olorunniji, F.J.,\&Eddouks, M. (2015). Medicinal plants used inmanagement of diabetes mellitus. Evidence based complementary and Alternative Medicine, 205.

6. Duraipandiyan, V., \&Ignacimuthu, S.(2007).Antibacterial and antifungal activity of Cassia fistula L. Ethano medical plant.J Ethnopharmacol, 112,590-594.

7. Bhakta, T., Banerjee, S.,Mandal, S.C., Maity, T.K., Saha, B.P.,\& Pal, M.(2001).Hepato protective activity of Cassia fistula leaf extract. Phytomedicine,8(3), 220-224.

8. Navanath, M.S., Naikwade, N.S., Mule, S.N.,\& Krishna, P.P.(2009). Evaluation of antiinflammatory activity of Cassia fistula and Ficusbengalensis, J Pharm Res. 2(8),S13041306. 
9.Kannampalli, P., Chandrashekaran, V.R.M., Kuppannan, G.,\&Sivanesan, K. (2007).Effect of C. fistula Linn. Leaf extract diethylnitrosamine induced hepatic injury in rats. J Chem-Biol Interactions, 167, 12-18.

10. Singh, M.P., Singh, A., Alam, G., Patel, R., \&Datt, N.(2012).Antipyretic activity of C. fistula Linn. Pods J Pharm Res, 5(5), 2593-94.

11. Jarald, E.E., Joshi, S.B., Jain, C.D.,\& Edwin, S.(2013).Biochemical evaluation of the hypoglycemic effects of extract and fraction of Cassia fistula Linn.In Alloxan-induced Diabetic Rats.Ind J Pharm Sci,75(4),427-434.

12. Pulok, K.M., Kuntal, M., Kakali, M.,\& Peter, J.H.(2006).Leads from Indian medicinal plants with hypoglycemic potentials. J Ethnopharmacol, 106, 1-28.

13.Malpani, S.N., Manjunath, K.P., Sholapur, H., Savadi, R.V., AkkiKusum, S.,\&Darade, S.S.(2015).Antidiabetic activity of Cassia fistula Linn. Bark in Alloxan Induced Diabetic Rats. Int J Pharma Sci,2(1),382-385.

14.Akhila, S., Aleykutty, N.A.(2015).Antidiabetic Activity Studies on Cassia fistula Fruits.Adv J Pharma Life Sci Res, 3(3),1-8. 54.

15.Soundiramani, B., Indumathy, R., Jayashree, N.,\&SakthiAbirami, M.(2016).Evaluation of in vitro anti-diabetic activity of various root extract of Cassia fistula L. Imperial $\mathbf{J}$ Interdisciplinary Res, 2(6), 758-761.

16.Patil, V.P., Amarshetty, N.A., Hugar, S., Nanjappaiah, H.M., Navanath, V.,\&Kalyane. (2016). Antihyperglycemic activity of Cassia fistula fruit extracts in streptozotocin-induced diabetes. Asian J PhytomedClin Res, 4(3),100107.

17. Silawat, N., Jarald, E.E., Jain, N., Yadav. A.,\&Deshmukh, T.P.(2009). The mechanism of hypoglycemic and antidiabetic action of the hydroalcoholic extract of Cassia fistula Linn. In rats. J Pharma Research,1,82-92.

18.Watt, G.(1972). Periodical Expert: Dictionary of the Economic Products of India, 1,260.

19.Saleem, T.S.M., Christina, A.J.M., Chidambaranathan, N., Ravi, V., \&Gauthaman, K. (2008).Hepatoprotective activity of Annona squamosal Linn on experimental animal model. Int J App Res Natu Pro,1(3),1-7.

20. Chen, Y., Xu, S.S., Chen, J.W., Wang,Y., Xu, H.Q., \&Fan, N.B. (2012). Anti-tumor activity of Annonasquamosa seeds extract containing annonaceousacetogenin compounds. $\mathbf{J}$ Ethnopharmacol,142(2),462-66.

21. Shah, R.(2011).Pharmacognosy and pharmacology of Annonasquamosa: A review. Int J Pharm \& Life Sci. 2,1183-9.

22. Pandey, N.,\&Barve, D.(2011).Phytochemical and pharmacological review on Annonasquamosa Linn. IJRPBS, 2(4),1404-1408. 
23. Tomar, R.S.,\&Sisodia, S.S. (2014).Antidiabetic activity of Annonasquamosa Linn. In alloxan-induced diabetic rats.Int J Green Pharm, 8(4), 237-241.

24.Gupta, R.K., Kesari, A.N., GeetaWatal, P.S., Murthy Chandra, R., Maithal, K., \&Tandon V. (2005).Hypoglycemic and antidiabetic effect of aqueous extract of leaves of Annonasquamosa (L.) in experimental animal. Current Science, 88(8),1244-124.

25. Ibrahim,,M., Mehjabeen, S.S., Narsu, M.L.(2011).Pharmacological evaluation of Catharanthusroseus.Int J Pharma App, 2(3),165-173.

26. Mahathi, K., Ramya, M.G., Samifar, S.K., Sindhuri, T.K., \&Madhuri.K.(2013).Evaluation of anti-ulcer activity of methanolic extract of Leaves of Catharanthusroseus in experimental rats. Der Pharmacia Lettre, 5(6),4347.

27. Marcone, A., Ragozzino, E.,\&Seemuller, E.(1997). Dodder transmission of alder yellows phytoplasma to the experimental host Catharanthusroseus (Periwinkle). Forest Pathology,27(6),347-350.

28. Gupta, P.(2009). Anti-estrogenic activity of petroleum ether extracts of the leaves of Catharanthusroseus (Vincarosea) in female albino mice. Asian J ExpSci, 23(1),313-316.

29.Jaleel, C.A., Gopi, R., Lakshmanan, G.M.A., \&Panneerselvam.R.(2006).Triadimefon induced changes in the antioxidant metabolism and ajmalicine production in Catharanthusroseus. (L.) G Don Plant Sci, 171(2),271-276.

30. Grag, V.K., \& Saini, D.(2006). Analgesic and anti-pyretic activity of ethanolic extracts of Leaves of Catharanthusroseus. Der Pharmacia Lettre, 8(18),48-52.

31.Balaabirami, S., \& Patharajan, S.(2012). In vitro antimicrobial and antifungal activity of Catharanthusroseus leaves extract against important pathogenic organisms. Int $\mathrm{J}$ Pharm PharmSci, 4(3),487-490.

32. Singh, S.N., Vats, P., Suri, S., Shyam, R., Kumria, M.M.,\&Ranganathan, S. (2001). Effect of an antidiabetic extract of Catharanthusroseus on enzymic activities in streptozotocin induced diabetic rats. J Ethnopharmacol, 76,269-277.

33. Ernst, E., Pittler, M.H., Stevinson, C., \&White, A.R.(2001). The desktop to guide to complementary and alternative medicine: an evidence based approach. J R Soc Med, 94(12), 650-651.

34. Gupta, A.P., Gupta, M.M.,\& Kumar, S.(19991).High-performance thin layer chromatography of asiaticoside in Centellaasiatica. J Indian ChemSoc, 76,321-322.

35. Hamid, A.A., Shah, Z., Mohamed Muse.,\& Mohamed, R.S.(2002). Characterization of anti-oxidative activities of various extracts of Centellaasiatica (L.) Urban.Food Chem, 77,465-469.

36.Kimura Y, Sumiyoshi M, Samukava K, Satake N, Sakanaka M. Facilitating action of asiaticoside at low doses on burn wound repair and its mechanism. Eur J Parmacol. 2008; 584(2-3):415-423. 
37. Gayathri V, Lekshmi P, Padmanabhan RN. Anti- diabetes activity of ethanol extract of Centellaasiatica (L) Urban (Whole Plant) is Streptozotocin- induced diabetic rats, isolation of an active fraction and toxicity evaluation of the extract. Int $\mathbf{J}$ Med Arom Plants. 2011; 1(3):278-286.

38. Emran TB, Dutta M, Uddin MMN, Nath AK, Uddin MZ. Antidiabetic potential of the leaf extract of Centellaasiatica in alloxan induced diabetic rats. J Biol Sci. 2015; 4(1):51-59.

39.Chauhan PK, Pandey IP, Dhatwalia VK.Evaluation of the Antidiabetic Effect of Ethanolic and Methanolic Extract of Centellaasiatica Leaves Extract on Alloxan Induced Diabetic Rats.AdvanBiol Res. 2010; 4(1):2730.

40. Kabir AU, Samad MB, Costa NMD, Akhter F, Ahmed A, Hannan JMA. Antihyperglycemic activity of Centellaasiatica is partly mediated by carbohydrase inhibition and glucose-fiber binding. BMC Complementary and Alternative Medicine.2014; 14:31.

41. Nayeemunnisa A. Alloxan diabetes-induced oxidative stress and impairment of oxidative defense system in rat brain: neuroprotective effects of Cichoriumintybus. Int J Diabetes and Metabolism.2009; 17:105-109.

42. Mehrandish R, Mellati AA, Rahimipour A, Nayeri ND. Anti-cancer activity of methanol extracts of Cichoriumintybus on human breast cancer SKBR3 cell line. RazaviInt J Medicine 2016; 5(1):E38369.

43.Ilayaraja N, Khanum F. Evaluation of antioxidant and toxicological properties of Cichory leaves. Int J Phrma Sci. 2010; 1(2):155-163.

44. Bothayna MA. Production of bakery products using two sources of inulin. Ann AgriSciMoshtohor, 2000; 38(1):361-378.

45. Mubeen F, Hardeep, Pandey DK. Anti-diabetic activity of methanolic extract of chicory roots in streptozotocininduced diabetic rats. Int J Pharm. 2013; 3(1):211-216.

46. Bakhru HK. Foods that heals (16th printing) orient Paperback, a division of Vision Book Pvt Ltd, India. 2000, 65-68.

47.Warrier PK, Nambiar VPK, Ramankutty C. Indian Medicinal Plants: A Compendium of 500 Species, Vol IV AryaVaidyaSala, Orient Longman Limited. Kottakal: 1996, 371.

48. Sridhar SB, Sheetal UD, Pai MSRM, Shastri MS. Preclinical evaluation of the antidiabetic effect of Eugenia jambolana seed powder in streptozotocindiabetic rats. Brazil J Med Bio Res. 2005; 38:463-468.

49. Waheed A, Miana GA, Ahmad SI. Clinical investigation of hypoglycemic effect of Eugenia jambolana in Type-2 (NIDDM) diabetes mellitus. Pak J Pharmacol. 2007; 24(1):1317.

50. Ravi K, Rajasekaran S, Subramanian S. Antihyperlipidimic effect of Eugenia jambolana seed kernel on streptozocin-induced diabetes in rats. Food and Chem. Toxicol. 2005; 43(9):1433-1439. 
51. Saravanan G, Leelavinothan P. Effect of Syzygiumcuminibark on blood glucose, plasma insulin and C-peptide in streptozotocin-induced diabetic rats. Int J EndocrinolMetab. 2006; 4(2):96-105.

52. Esther GS, Manonmani AJ. Effect of Eugenia jambolana on streptozotocin-nicotinamideindued type-2 Diabetic Nephropathy in Rats.Int J Drug Dev\& Res. 2014; 6(1):175-187.

53.Renuga G, Thamizhvanan K. Compensatory hypoglycemic effect of Eugenia jambolana seed derived bio molecules in streptozotocin-induced diabetic rats. J PharmaSci Innovation. 2014; 3(1):57-61.

54. Kumar A, Ilavarasan R, Jayachandran T, Decaraman M, Aravindhan P, Padmanabhan N et al. Anti-diabetic activity of Syzygiumcumini and its isolated compound against streptozotocin-induced diabetic rats. J Med Plants Res. 2008; 2(9):246-249.

55. Nisha TU, Qadir MI, Malik SA. Anti-diabetic activity of inorganic metals of Eugenia jambolana Lam. (Myrtaceae) flowers.Pharmacology online. 2010; 2:979985.

56. Esther GS, Manonmani AJ. Effect of Eugenia jambolana on streptozotocin-nicotinamideindued type-2 Diabetic Nephropathy in Rats.Int J Drug Dev\& Res. 2014; 6(1):175-187.

57. Altan MV. The pharmacology of diabetic complications.Curr Med Chem. 2003; 10(15)1317-1327.

58. Sathya S, Kokilavani R, Gurusamy K. Hypoglycemic effect of Gymnemasylvestre (retz.,) $\mathrm{R}$. Br leaf in normal and alloxan induced diabetic rats. AncSci Life. 2008; 28(2):12-14.

59.Kumar A, Gnananath K, Gande S, Goud E, Rajesh P, Nagarjuna S. Anti-diabetic Activity of Ethanolic Extract of Achyranthesaspera Leaves in Streptozotocin induced diabetic rats. Journal of Pharmacy Research.2011; 4: 3124-5.

60. Chopra R.N., Nayar S.L., Chopra I.C: Glossary of Indian medicinal plants. C.S.I.R., New Delhi (1956).1999: 2-23.

61.Jain A., Katewa S.S., Galav P.K., Sharma, P.: Medicinal plant diversity of Sitamata wildlife sanctuary, Rajasthan, India. J. Ethnopharmacol 2005; 102(2): 143-157.

62.Jain A.K., Shimoi K., Nakamura Y., Tomita I. And Kada T. Preliminary study on the desmutagenic and antimutagenic effect of some natural products. CurrSci 1987; 56: 12661269.

63.Joshi S.G.: Medicinal Plants I.B.H. Delhi, 2007: 270-271.

64.Kubmarawa D., Ajoku G.A., Enwerem N.M., Okorie D.A.: Preliminary phytochemical and antimicrobial screening of 50 medicinal plants from Nigeria. Afr. J. Biotechnol 2007; 6(14): 1690-1696.

65.Chowdhury A.R., Baberji R., Mishra G. And Nigam S.K.: Chemical composition of Acacia seeds. J Am Oil ChemSoc 1983; 60: 1893-1894. 
66.Gupta PD, De A. Diabetes Mellitus and its herbal treatment. International Journal of Research in Pharmaceutical and Biomedical Sciences. 2012; 3(2): 706-21.

67.Gupta PD, De A. Diabetes Mellitus and its herbal treatment. International Journal of Research in Pharmaceutical and Biomedical Sciences. 2012; 3(2): 706-21.

68. Dinesh Kumar, Sunil Kumar, Sonia Kohli, RenuArya, Jyoti Gupta. Antidiabetic activity of methanolic bark extract of AlbiziaodoratissimaBenth. in alloxan induced diabetic albino mice. Asian Pac J Trop Med 2011; 900-903.

69. Ohadoma SC, Michael HU. Effects of co-administration of methanol leaf extract of Catharanthusroseus on the hypoglycemic activity of metformin and glibenclamide in rats. Asian Pac J Trop Med 2011; 475-477.

70.Ibeh BO, Ezeaja MI. Preliminary study of antidiabeticactivivty of the methanolic leaf extract of Axonopuscompressus (P.Beauv) in alloxan induced diabetic rats. J Ethnopharmacol 2011; 138: 713-716.

71. Kumar R, Patel DK, Prasad SK, Laloo D, Krishnamurthy S,Hemalatha S. Type 2 antidiabetic activity of bergeninfromthe roots of CaesalpiniadigynaRottler. Fitoterpia2012;83(2): 395-401.

72.Sethi J, Sood S, Seth S, Talwar A. Evaluation of hypoglycemic and antioxidant effect of Ocimum sanctum. Indian J ClinBiochem. 2004; 19(2): 152-5. doi: 10.1007/BF02894276, PMID: 23105475, PMCID: PMC3454204.

73 Vats V, Grover J, Rathi S. Evaluation of anti-hyperglycemic and hypoglycemic effect of Trigonellafoenum-graecum Linn, Ocimum sanctum Linn and Pterocarpusmarsupium Linn in normal and alloxanized diabetic rats. J Ethnopharmacol. 2002; 79(1): 95-100. doi: 10.1016/S0378-8741(01)00374-9.

74Shetti A, Sanakal R, Kaliwal B. Antidiabetic effect of ethanolic leaf extract of Phyllanthusamarus in alloxan induced diabetic mice. Asian J Plant Sci Res. 2012; 2(1): 11-5.

75. Patil SP, Niphadkar PV, Bapat MM. Allergy to fenugreek (Trigonellafoenumgraecum) Ann Allergy Asthma Immunol, 1997; 78:297-300.

76. Sharma RD, Raghuram TC, Rao NS. Effect of Fenugreek seeds of blood glucose and serum lipids in type 1 diabetes. Bur J ClinNutri. 1990; 44(4):301-306.

77.Kumar M, Prasad M, Arya RK. Grain yield and quality improvement in fenugreek.A review. Forage Research 2013; 39(1):1-9.

78. Mishkinsky JS, Goldschmied A, Joseph B, Ahronson Z, Sulman FG. Hypoglycemic effect of Trigonellafoenumgraecum and Lupinustermis(Leguminosae) seeds and their major alkaloids in alloxan-diabetic and normal rats. Arch IntPharmacodynTher. 1974; 210(1):27-37.

79.Patil SP, Niphadkar PV, Bapat MM. Allergy to fenugreek (Trigonellafoenumgraecum) Ann Allergy Asthma Immunol, 1997; 78:297-300. 
80.Gupta A, Gupta R, Lal B. Effect of Trigonellafoenumgreacumseeds on glycaemic control and insulinresistance in type 2 Diabetes mellitus. J Assoc Physicians India.2001; 49:10571061 .

81. Laila O, Murtaza I. Fenugreek: A treasure of bioactive compounds with promising antidiabetic potential. Int J Food and Nut Sci. 2015; 4(1):149-157.

82.Sarasa D, Sridhar S, Prabakaran E. Effect of an antidiabetic extract of Trigonellafoenumgraecumon normal and alloxan-induced diabetic mice. Int J Pharm PharmSci, 2012; 4(1):6363.

83.Christy AO, Mojisola COC, Taiwu EO, Ola OO. The Antimalaria effect of MomordicacharantiaL. andMirabilis jalapaleaf extracts using animal model. J Med Plants Res. 2016; 10(24):344-350.

84.Jerald SE, Pandey A, Bigoniya P, Singh S. Antifertility activity of Momordicacharantiadescourt pulp and seed hydroalcoholic extract. J App Pharm. 2012; 3(4):682-696.

85.Vinav G, Jigna V, Mohaddesi B. Phytochemical ainvitroantihelmintic activity of MomordicacharantiaLinn. Fruit extracts. Int J Res Ayurveda Pharm. 2016;

7(1):123-127.

86.MamunMd MAM. A study on hypoglycemic effects of Momordicacharantia(Wild Variety) in alloxan induced Type 2 diabetic long-evans rats. ClinBiochem. 2011; 44(13):S116.

87.Perumal V, Khoo WC, Hameed AA, Ismail A, Saari K, Murugesu S et al. Evaluation of antidiabetic properties of Momordicacharanxtiain streptozotocin induced diabetic srats using metabolomics approach. Int Food Res Journal. 2015; 22(3):1298-1306.

88. Prabu KA, Kumarappan CT, Christudas S, Kalaichelvan VK. Effect of B.sensitivum on streptozotocin and nicotinamide induced diabetic rats. Asian Pac J Trop Med. 2012;2:31-35 